\title{
Readings of Homosexuality in Mary Shelley's Frankenstein and Four Film Adaptations
}

\author{
Michael Eberle-Sinatra Université de Montréal
}

\begin{abstract}
Movies speak mainly to the eyes. Though they started talking in words some seventy years ago, what they say to our ears seldom overpowers or even matches the impact of what they show us. ${ }^{1}$
\end{abstract}

[T] hey brought out Frankenstein at the Lyceum ... and [they] vivified the Monster in such a manner as caused the ladies to faint away \& a hubbub to ensue. ${ }^{2}$

This essay proposes to read one more time the issue of homosexuality in Mary Shelley's first novel, Frankenstein. In order to offer a new angle on the homosexual component of Victor Frankenstein's relationship with his creature when next teaching this most canonical Romantic novel, this essay considers Shelley's work alongside four film adaptations: James Whale's 1931 Frankenstein, Whale's 1935 The Bride of Frankenstein, Richard O'Brien's 1975 The Rocky Horror Picture Show, and Kenneth Branagh's 1994 Mary Shelley's Frankenstein. ${ }^{3}$ These films present their audience with original readings of their source material, readings that can be questioned with regards to their lack of truthfulness to the original work's themes and characters.

Obviously, the notion of presupposing knowledge of the author's original intention on my part, and thus arguing for subsequent misreading of her work by these three film directors, is quite problematic in itself. This essay is not intended to contribute further to the debate of adapting a novel into another medium, and it argues instead for the fluidity of Shelley's novel, particularly around the issues of sexuality and masculinity as found in Victor's and Walton's scientific endeavors. This fluidity is however limited in all four films under consideration because of directorial decisions that restrict and potentially misinterpret Shelley's work. The creation scene in particular in Whale's and Branagh's films demonstrate the extent of one such reading involved in these film adaptations in light of what Shelley's novel actually presents to the reader. O'Brien's film, on the other, takes on the sexual content of Frankenstein full steam, and it presents the audience with probably the most daring interpretation of the sexual politics of the novel, a treatment 
of Shelley's story that arguably enriches in turn any reading of the sexual aspect in Frankenstein.

Although science seems to be the unifying principle behind the main story of the novel and most film adaptations, this essay will show how Shelley incorporates science and sexual orientation within her novel in a way that differs significantly from the films, especially Whale's and Branagh's films. There is indeed an engaging dialogue between these film adaptations and the original novel, particularly in the construction of science as the dominant over-arching narrative and the visual presence of scientific apparatus in the former, and as the absent other in the latter. Whale and Branagh reclaim Science as a significant element of the story, and it exemplifies a reading of Shelley's attempt at displacing the scientific discourse, with all its gender politics, outside the novel that is interpreted with quite different results by the directors. Similarly, Shelley's decision to leave the sexual politics of her novel open for interpretation is construed by both directors as a strict heterosexual agenda, even their directorial decisions indicate that this interpretation is only to be found on the surface.

Although most readers are probably limiliar with shelley's story, a skekd of the extual construction of the book is useful in order to point out some of the differences between the novel and the four cinematographic adaptations under consideration. Frmbenstem is an open ended series of dialogues between present and absent characters, between active male and passive female dhaketers, and between science fact and science fiction. The re-lelling of Victor lrankenstein's tale by Robert Walton to his sister Margaret Walton Saville in a series of letter's places Victor's story within a narrative frame. Enclosed within Walton's epistolary writing is Victor's (re)telling of the Creature's narration of his story. The very nature of a novel as written text is made explicitly obvious by Shelley's use of the epistolary genre, though she also cleverly makes speech a key feature of her story by depicting an oral exchange with the reported discussions that take place between Victor and Walton, Victor and the Creature, and the Creature and Walton.

Victor's tale consists of a series of episodes, chronologically arranged, which describe his childhood, his training as a doctor, the creation of his Creature, and the events that follow this act, namely the deaths of his entire family, save one of his brothers, and of his best friend, Henry Clerval, and his fiancée, Elizabeth. Throughout the novel, Walton, though very sympathetic to Victor from the first moment they meet, questions the veracity of Victor's story. The questioning elements of the dialogues between both male and female characters, and indirectly between Shelley and her readers, create a particular atmosphere of uncertainty regarding the veracity of the story, or at least the extent to which all the details have been put on paper. This ambiguity is one of the contributing factors to the openended approach Shelley chooses to adopt in her novel. By undermining her narrator's retelling of Frankenstein's story (Is Walton telling the reader everything? What 
about Margaret's role and influence as recipient of Walton's letters, and consequently her implied role as editor of the story?), the text invites the reader not to rush judgment on the various elements at play in her novel, including sexual politics.

Robert Walton is an important character in Frankenstein, not only because he provides the frame narrative to Victor's story, but also because of Walton's numerous references to male companionship and his description of Victor as 'the brother of my heart'. ${ }^{4}$ Walton's relationship to Victor in the novel can be read as an instance of repressed homosexuality or, more precisely, as a case of the kind of homosexual narcissistic love that Freud describes in 'Three Essays on the Theory of Sexuality'. Indeed, Walton praises Victor for the characteristics they both share, such as their educational backgrounds and their goals in life. Both assert that their research - the search for the secret of life for one, and for a passage from England through the North Pole to North America for the other - will benefit humanity as a whole, even when their goals in fact put other people's lives in danger, be they Victor's family and friends or the crewmen aboard Walton's ship.

The homoerotic dimension of the novel is worth underlining because, as Mark Simpson notes, 'when revealed, [such a dimension] is the greatest challenge to virility and thus masculinity's claim to authenticity, to naturalness, to coherence - [in other words] to dominance. ${ }^{5}$ This challenge to virility is largely what Whale and Branagh try to prevent. ${ }^{6}$ Their attempts at concealing such a reading emerge in part from the very nature of mainstream cinema and its relationship to homosexuality. Steve Neale describes this very well when he remarks that,

the spectatorial look in mainstream cinema is implicitly male: it is one of the fundamental reasons why the erotic elements involved in the relations between the spectator and the male image have constantly to be repressed and disavowed. Were this not the case, mainstream cinema would have openly to come to terms with the male homosexuality it so assiduously seeks either to denigrate or deny. As it is, male homosexuality is constantly present as an undercurrent, as a potentially troubling aspect of many films and genres, but one that is dealt with obliquely, symptomatically, and that has to be repressed.?

Whereas readings of homosexuality, masturbation, and narcissistic love in Frankenstein are not hard to come by in scholarly works, critics have not generally discussed these sexual elements in Whale's and Branagh's films. However, there are many reasons for exploring such a reading, especially in light of the way these film adaptations significantly differ from Shelley's novel and its description of the sexual relationship between the Creature and Victor. ${ }^{8}$

The language used to describe the making of the Creature by Victor in the novel suggests masturbation, as Gordon D. Hirsch and David E. Musselwhite have pointed out. ${ }^{9}$ Victor describes how he uses his 'profane fingers' in a 'solitary chamber' where he keeps his 'workshop of filthy creation', and he complains that his 'heart often sickened at the work of my hands' $(32,113)$. These masturbatory elements also suggest homosexual fantasies. As Judith Halberstam notes, 
The endeavor of Frankenstein to first create life on his own and then prevent his monster from mating suggests, if only by default, a homoerotic tension which underlies the incestuous bond ... His creation of 'a being like myself' hints at both masturbatory and homosexual desires which the scientist attempts to sanctify with the reproduction of another being. ${ }^{10}$

A Freudian reading of Frankenstein would also confirm the homosexual dimension of the relationship existing between Victor and the Creature since Victor's 'sense of persecution represents the fearful, phantasmic rejection by recasting of an original homosexual (or even merely homosocial) desire, then it would make sense to think of [Frankenstein] as embodying strongly homophobic mechanisms." Because they omit the numerous references to Victor's feeling of persecution that one finds in the novel, both Whale's and Branagh's films seem to present an inter esting alternative to this kind of reading, or at least at first.

In both Frankenstein and The Bride of Frankenstein, Whale emphasises Victor's heterosexuality by replacing Victor's solitary relationship with the Creature by a more social and public one. The possibility of any social interaction between Victor and the Creature that might result in a homosocial / homosexual subtext is basically removed by Whale since, whereas Shelley's Creature is highly intelligent and intellectually attractive for Victor, Whale's monster cannot speak in the 1931 film, and can barely articulate a few words in the 1935 sequel. Whale's 1935 film also offers the Creature a female companion, if only for a limited time, when in the novel Victor destroys the female creature he is working on, thus climinating any potential heterosexual competition for the Creature's attention. In both films, Whale also chooses to have Victor proceed with his experiments with the help of either Fritz or Dr Pretorius, and other characters actually witness his work. This socially active Victor prevents consequently any reading of his personal motive in his making of the creature and the possible relationship that would ensue. Whale still hints at Victor's possible homosexuality in his relationship to Fritz, and most specifically in all his scenes with Dr Pretorius, a character culturally encoded as 'deviant', i.e. homosexual, who thus underscores Whale's subtle, ironic retelling of Shelley's story - he replaces Victor's homosexual interest in the Creature with another man.

The character of Elizabeth in both Whale's films and Branagh's 1994 film reinforces further Victor's heterosexuality. Each film implicates Elizabeth in Victor's experience, and thus removes the option of a homosexual reading of the creation scene. Whale modifies this scene in both films to incorporate an audience, one which includes Elizabeth. In fact, in Whale's Frankenstein, Victor at first refuses to permit Dr Waldman and his friend Victor Moritz to disturb his experiment, and he specifically instructs Fritz not to allow anyone in. However, when Elizabeth asks him to open the door, he yields and actually shows loving concern for her. The tone that Frankenstein uses to talk to Moritz also differs significantly from the one he uses with Elizabeth, another instance of his heterosexual attachment to her. As for Branagh, although he does not include Elizabeth in his creation scene, he adds an extra scene beforehand. Fearing that Victor might be involved with another 
woman, Elizabeth decides to go to Geneva to ask him to come home with her. Although Victor stays to pursue his experiment, the preceding scene is reinforces Victor's commitment to Elizabeth. To a large extent, both directors seem to offer readings of the novel that emphasize the characters' heterosexuality without including Shelley's critique of her male characters, and her deliberate openness regarding questions of sexuality.

Indeed, the films never seem to question Victor's sexuality but on the contrary repeatedly emphasize his heterosexuality whereas the novel leaves this aspect of Victor's character more open to discussion. The novel's Victor is obsessed with the Creature, who repeatedly makes his pulse beat faster and his brow sweat. For instance, Victor declares: 'I remembered also the nervous fever with which I had been seized just at the time that I dated my creation' (49). Victor also reacts nervously when his father comments:

For some time I was lost in conjecture as to the cause of [your unhappiness]; but yesterday an idea struck me, and if it is well founded, I conjure you to avow it. Reserve on such a point would not only be useless, but draw down treble misery on us all. (103)

Victor reacts by 'trembl[ing] violently at this exordium' (103). His father proceeds to suggest, with much more prescience than Victor gives him credit for:

you may have met with another whom you may love; and considering yourself as bound in honour to your cousin, this struggle may occasion the poignant misery which you appear to feel. (104)

Victor reassures him that he loves his cousin, but he does so in terms that leave open the possibility that he might love a male other: 'I never saw any woman who excited, as Elizabeth does, my warmest admiration and affection' (104; emphasis mine). The possibility that Victor might have met another man clearly does not occur to his father, and to a certain extent neither does this possibility occur to Victor himself, though he is certainly much more excited physically by the thought of the Creature and its physical presence than he is by Elizabeth.

Later on in the novel, the possibility of Victor's love for another person is brought up again, this time by Elizabeth herself, when she asks: 'Answer me, I conjure you, by our mutual happiness, with simple truth - do you not love another?' (130). Margaret Homans comments that 'This is in fact the case, for the demon, the creation of Frankenstein's imagination, resembles in many ways the romantic object of desire, the beloved invented to replace, in a less threatening form, the powerful mother who must be killed.' ${ }^{12}$ However, what if the Creature had really become Victor's 'romantic object of desire' and not only the embodiment of his Oedipus complex? The manuscript version of the novel also offers a supplementary argument for the possibility of homosexual love. In the draft version of this passage, Shelley wrote: 'Answer me, I conjure you by our mutual happiness, with simple truth do you not love another?.' ${ }^{13}$ By deleting any mention of a wife, Shelley leaves the gender of Victor's possible other love unspecified. Shelley explores the issues of heterosexuality and masculinity further, 
though still in undetermined terms, when she describes the creation of Victor's creature.

\section{II}

Whereas the two directors treat the creation scene as the climactic moment in their films, Shelley is much more understated in her depiction of the scene. Branagh is obviously also responding to Whale's film and other film adaptations with his own creation scene. It is actually quite ironic that Whale's creation scene has become the standard for film versions of Shelley's novel in so far as his film was not based directly on the novel itself but on the very successful 1927 play Frankenstein: An Adventure in the Macabre, written by Peggy Webling. This explains many of the changes that take place in Whale's film, such as the change of Victor's name to Henry and the inclusion of the dwarf assistant Fritz (a character who was present in most nineteenth-century dramatic adaptations of the novel, often for comic relief). It also explains why Whale's version of the creation scene feels like Victor is performing his experience in front of his guests. Victor actually declares: 'Quite a good scene, isn't it? One man crazy! Three very sane spectators!'14

Brian Easlea reads Frankenstein as an exposure of what he calls 'the compulsive character of masculine science', in other words a display of a distinctly male scientific obsession, a reading that Whale and Branagh would no doubt agree with. ${ }^{15}$ It is true that, as Brian Aldiss mentions, '[Shelley] appeals to scientific evidence for the veracity of her tale.'16 Yet, I would argue that the scientific discourse is, to borrow Derrida's words, 'en retrait' in the novel. 'En retrait' means both retracted, that is, taken out of the narrative, and re-traced, or re-inscribed within the narrative. In other words, Shelley integrates the scientific dimension of her novel within the text by simultaneously eliminating traces of science and re-tracing these elements in the sub-text of the main narrative. This is true for instance in the case of Victor's early interest in science, which Shelley describes in the manuscript version, but chooses not to include in the published version of the novel. This is also particularly true of the scene describing the creation of the Creature. Whereas the reader would expect to be told how the experiment is conducted, Shelley elides the details of the creative process. Her unwillingness to elaborate on the life-giving apparatus may be a deliberate gesture, for Victor's machine could pose an immediate threat to her exclusive ability as a woman to give birth. Writing science in Frankenstein thus becomes an act of denial, resulting in a meaningful silence. As opposed to the genesis of the universe as told in the Bible, where the Word is the beginning of all creation, Shelley literally unspeaks the birth of the Creature. The absence of description frustrates all male attempts at emulating natural birth, attempts which cannot but end in destructive chaos and annihilation. Shelley's husband sympathises with his wife's views when he writes in the 1818 preface that the 'physical fact [of artificial reproduction is] impossible' (5), thereby stressing that giving birth is a female prerogative. It is obvious that Victor suffers from 'womb envy.' ${ }^{17}$ In fact, his whole project shows the extent of his wish to supplement 
women's reproductive power with a (male) scientific approach to the creation of life. The haunting quality of the Creature's final speech, containing the phrase, 'I, the miserable and the abandoned, am an abortion' (155), also leaves little room for misinterpretation.

It is interesting to note that Shelley, in the 1831 preface, highlights the fact that she, and she alone, was capable of producing a complete story in the ghost writing contest that took place in the summer of 1816, thus underscoring a parallel between female productivity and the privilege of female reproduction. Shelley's life was very much lived under the shadow of several men, particularly her father, to whom Frankenstein is dedicated, her husband the poet Percy Bysshe Shelley, and another poet Lord Byron, both of whom can be seen as depicted in Shelley's Frankenstein and her 1826 novel The Last Man under the various characters of Victor Frankenstein, Clerval, Adrian and Lord Raymond. Shelley also very much lived under the expectation of these men to fulfill her biological role of mother and the more unusual role of author. In other words, Chris Baldick rightly perceives the creation of the Creature and Victor's attempt at transgressing the rules of nature as an expression of her 'mixed feelings, both assertive and guilty, of the adolescent for whom fully adult identity means both motherhood and (in her circle) authorship too.' 18 One needs only to turn to the preface to the third edition of Frankenstein in 1831 to realize this: 'My husband . . . was from the very first very anxious that I should prove myself worthy of my parentage and enrol myself on the page of fame. He was forever inciting me to obtain literary reputation' (170). She then goes to describe the origin of Frankenstein during the summer of 1816 when she stayed in Switzerland with P. B. Shelley, Byron, Polidori, and her stepsister Claire Clarmont (although the latter is not mentioned in the preface - a personal rancor against Claire or an unconscious case illustrating again the repression of women?). "We will each write a ghost story", said Lord Byron, and his proposition was acceded to' (170). Then, she tells us of the pressure that was building up everyday for her to enter the realm of authorship: 'Have you thought of a story? I was asked each morning, and each morning I was forced to reply with a mortifying negative' (171). Again and again she keeps on trying to think of a story but without success, until one day she had her prophetic vision of 'the pale student of unhallowed art kneeling beside the thing he had put together' (172). In many ways, Frankenstein can be seen as the putting together by Mary Shelley of her experience as a writer transgressing the conventional passive role attributed to women in her society.

As previously mentioned, Shelley is very elusive on the actual experiment and its proceedings in her novel. The fourth chapter opens with the following paragraph, in which Victor declares:

It was on a dreary night of November, that I beheld the accomplishment of my toils. With an anxiety that almost amounted to agony, I collected the instruments of life around me, that I might infuse a spark of life into the lifeless thing that lay at my feet. It was already one in the morning; the rain pattered dismally against the panes, and my candle was nearly burnt out, when, by the glimmer of the half-extinguished light, 
I saw the dull yellow eye of the creature open; it breathed hard, and a convulsive motion agitated its limbs. (34)

Victor meditates for a moment on his achievement and, as he tells Walton, 'unable to endure the aspect of the being I had created, I rushed out of the room, and continued a long time traversing my bed-chamber, unable to compose my mind to sleep' (34). That's it. No lighting bolt, no giant piece of machinery, and definitely not the famous cry that the actor Colin Clive utters in Whale's film: 'It's alive! Alive!. This aspect of the novel ultimately proves quite useful to most directors, as Branagh argues:

Perhaps the most abiding and astonishing thing is the novel's very unspecific evocation of the creation process: Shelley almost completely ignores the details. It is a stroke of brilliance, really, because it allowed artists in other mediums to interpret that part of the story in many imaginative and exciting ways. ${ }^{19}$

The preface to the 1831 edition contains a more detailed description of this scene as Shelley imagined it. Here, Shelley describes the mental vision which triggered the writing of the novel:

I silw the pale student of unballowed arts kneeling beside the thing he had put together. I salw the hideous phantiasm of a man stretched out, and then, on the working of some powerful engine, show signs of life, and stir with uncasy, half-vital motion. (172)

Whereals the novel lacks a detailed description of the generation of the Creature, every cinematographic adaptation contains a creation scene. 'l'his is explained in part because of the popular success of Whale's 1931 film that imposes a cultural burden on subsequent filmmakers. Whale's famous creation scene, with its scienlific apparatus or 'engine' and light ning bolts, has become the standard interpretation of Shelley's novel, and viewers automatically compare any film adaptation with Whale's. The nature of cinema itself implies the necessity of familiar visual elements for its viewers. As Jean-liançois lyotard observes, the notion of the reeognizable is the basic requirement for a cinematic experience to take place:

The image must cast the object or set of objects as the double of a situation that from then on will be supposed real. The image is representational because recognizable,

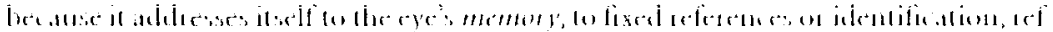

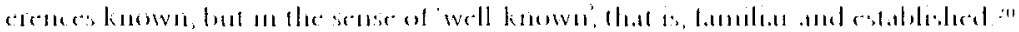

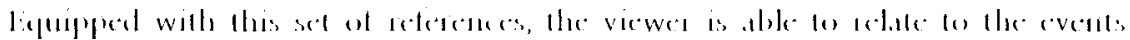

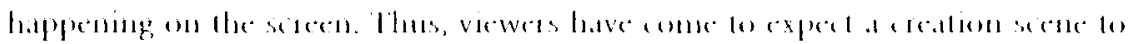

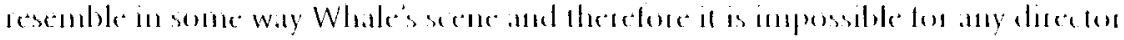

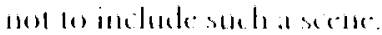

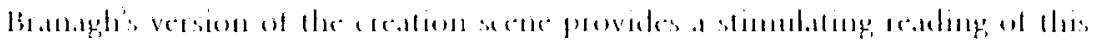

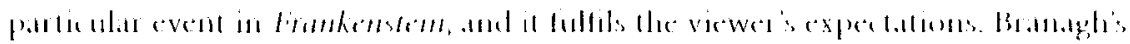

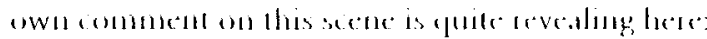

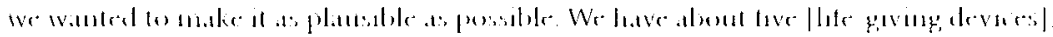

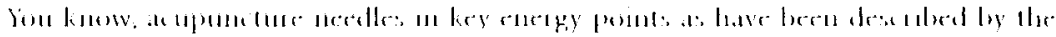


Chinese for thousands and thousands of years, and amniotic fluid as a kind of biogenic agent. We threw electric eels into the mix 'cause then you've got a very sexual image. We have them in a huge kind of scrotum and they come down a huge tube into a great sort of womb and fertilize this embryonic Creature. ${ }^{21}$

Branagh is right to interpret the creation scene from the novel as a crucial part of the story, although its importance does not stem from the sources he supposes. Whereas Shelley undermines the male attempt at replacing women and displaces the scientific dimension of this scene into a meaningful non-description, Branagh does more than just re-inscribe science as the major element of Frankenstein: he makes it the major part of this scene, and the climax of his film. Aldiss provides an interesting gloss on this scene:

In Branagh's film, amino acids are injected into the Creature's feet and it is born in or tipped out of - a copper bath full of amniotic fluid, in a striking approximation of real birth. Child and father... splash together nakedly in the gushing waters. This may not have happened in the book, but it certainly does in the sub-text. ${ }^{22}$

The creation scene is indeed a birth scene in its own right, but it also contains some glaring homoerotic tension that Branagh may not have fully anticipated.

Branagh's film adds a very explicit sexual dimension to the creation / birth scene. In his version of the scene, the actor Branagh, who plays Victor in the film, attempts to help his Creature stand amidst the slippery amniotic fluid. Bouriana Zakharieva's description draws out the complex implications of Branagh's direction: 'Creator and creation embrace in an ambivalent scene of struggle and affection; their hug is an expression of a desire to separate from each other and at the same time to help each other stand erect.'23 Zakharieva accurately anticipates the rejection of the Creature and she invites, perhaps unwittingly, a reading of this scene in sexual terms by her choice of the words 'stand erect'. Branagh physically supports his Creature, administers a cardiac massage and ultimately engages in what looks like an enticing parody of sexual intercourse, which reflects the homosexual side of his character in the film, as well as in the novel. The Creature is referred here as 'him' because it is assumed to be male by Victor, who more than anyone else should know. Actually, the manuscript version of the novel contains a more precise description of the Creature: 'it was on a dreary night of November that I beheld my man completeed [sic]'.24 For a modern reader, 'my man' has a certain double-entendre. However, in the published version, Shelley chose to replace 'my man' with 'the accomplishment of my toils', thus offering the reader an ungendered Creature, a being defined sexually only by Victor and his relationship to it.

In Branagh's film, the 'birth' of the Creature is a highly erotic scene. Viewers see the Creature naked, and the actor Branagh engaged in his act of creation topless, sweating, and visibly very excited by the whole affair. That Branagh's body is so exposed is in itself unusual in Hollywood films. Indeed, as Paul Burston remarks in his discussion of popular cinema,

Historically, popular cinema has shied away from presenting sexually explicit images of its male stars. Of course this is no accident. Socially and cinematically, male 
authority is bound up with the act of looking. Any representation of masculinity denoting 'to-be-looked-at-ness' is therefore perceived as a threat to dominant notions of what it means to be a 'real' (i.e. rigidly heterosexual) man. ${ }^{25}$

Thus, even though Branagh may not have intended such a reading of his film, his choice to expose himself is one of the elements that points to its homosexual dimension. Branagh uses the famous lines from Whale's classic version of the novel - 'it's alive - it's alive' - but he pronounces them more slowly, as if realizing for the first time what he has just achieved. After following the tapping of the Creature's hand against its artificial womb, the camera angle closes in on Branagh's physical presence, framing only his hairy, sweaty torso and thus offering another detailed shot of his masculine anatomy. Making good use of the cinematographic medium, Branagh combines music and rapid movements of the camera to emphasize the growing excitation of his own character. Yet, Branagh is not fully aware of the source of his character's excitement.

In the end, Victor's ultimate rejection of his own offspring, in the novel as well as in Whale's and Branagh's films, illustrates the male inability to deal with the trauma of after-birth, as Ellen Moers eloquently summarises. ${ }^{26}$ It is not surprising that Victor rejects the finished product of his experimentation - the body of his Creature - upon his completion of it. Deleuze's discussion of the body in Cinema 2: The Time Image is particularly relevant here: 'Not that the body thinks, but, obstinate and stubborn, it forces us to think, and forces us to think what is concealed from thought, life?? By contemplating the body of the Creature, Victor is reminded of the principle of life and the ultimate failure of his artificial construct. However, there is also the possibility that Victor is reacting to his own sexuality when he is confronting the naked body of his Creature. Branagh's film provides again one of the most telling readings of this confrontation. When the Creature finds himself hanging in the air, unconscious and completely exposed to Branagh's eyes (though of course the Creature's anatomy is not shown, being shrouded in a protective shade, maybe in fear of exposing another monstrous part?), Branagh declares. 'what have I done?'. ${ }^{28}$ Is this only a moral reaction to his experiment, or is he reacting to the undepictable sexual apparatus of his creation, with all that it connotes for his own sexuality? In contrast to Whale's and Branagh's film adaptations, with their conflicted views of science and sexuality, Richard O'Brien's Rocky Horror Picture Show offers an explicit reading of what Frank N. Furter, a.k.a Victor, had in mind when he created his creature.

\section{III}

The relationship between the Rocky Horror Picture Show and Shelley's novel is of course obvious. In fact, the playbill for the first performance of the Rocky Horror play, at the London Theatre Upstairs on 16 June 1973, promised, as Stuart Samuels notes, 'something for everyone, a 'rock ' $n$ ' roll horror fantasy' based on the Frankenstein theme. ${ }^{29}$ The Rocky Horror Picture Show is indeed closely based on the novel, with, to mention but three instances, the third song performed entitled 
'Over at the Frankenstein Place', the most celebrated character of the film called Frank N. Furter, and Rocky, the new, postmodern embodiment of Victor Frankenstein's famous creature. References to James Whale's Frankenstein and The Bride of Frankenstein also contribute to an obvious identification of the film's source, as for instance with the laboratory scene which clearly evokes Whale's Frankenstein, and Magenta's hairstyle at the end of the film which is a direct parody of the Bride's hairstyle in Whale's Bride of Frankenstein. As previously discussed, the theatricality of Whale's films resulting from their use of Peggy Webling's play as a source for the original screenplay, as well as Whale's own theatre career, is another common trait with The Rocky Horror Picture Show, a film that remains true to its theatrical and literary origins.

For readers unfamiliar with O'Brien's film, based on his own 1973 musical, the story, in brief, develops as follows. On their way to their old teacher Dr Everett Scott's house to announce their engagement, a flat tire delays Brad Majors and Janet Weiss. They are obliged to seek help at a nearby castle. There, they happen upon the Transylvanian Society in the midst of its annual meeting, under the presidency of Frank N. Furter, who describes himself as 'a sweet transvestite from Transsexual Transylvania.' Frank invites Brad and Janet to witness the birth of his creature, Rocky, in a laboratory scene which is very closely based on Whale's. Frank then introduces Rocky to the assembled crowd as a creation intended for his personal sexual pleasure. As soon as Rocky has had the opportunity to show off his muscular body, Frank disappears into the nuptial bedroom with him. That same night, Frank seduces in two separate sexually explicit scenes both Brad and Janet. Janet, distressed by her fiancé's infidelity and her own newly awakened sexuality, proceeds in turn to seduce Rocky. They are interrupted by the sudden arrival of Dr Scott, in search of his missing nephew Eddie (whose brain Frank pillaged for Rocky). Frank then co-opts his guests into his floorshow, where each will assert his or her newfound sexual liberation thanks to Frank's influence. Ultimately, Riff Raff and Magenta, two incestuous sibling aliens acting as Frank's servants, kill both Rocky and Frank. The castle is then transported back to Transylvania, leaving Dr Scott, Brad, and Janet dazed and bewildered.

The audience is also often bewildered for The Rocky Horror Picture Show modifies cinematographic conventions by presenting an alternative to the restrictive binary categories of male and female, just as Shelley presents a more complex take on issues of sexuality and masculinity in her novel. Neale argues that in mainstream cinema

there is constant work to channel and regulate identification in relation to sexual division, in relation to the orders of gender, sexuality, and social identity and authority marking patriarchal society. Every film thus tends to specify identification in accordance with the socially defined and constructed categories of male and female. ${ }^{30}$

The film introduces a bisexual approach to the characters' sexuality, which opens their minds to an array of confusing possibilities, as well as unsettling the audience. The beauty of the film's batty eroticism is its polymorphous perversity. It is 
absolutely inclusive, and liberating for that reason. In its open outrageousness and campiness, The Rocky Horror Picture Show allows the viewer to supplement several conventional elements present in mainstream cinema by other, less strictly defined categories of sexual identity, gender relationships, and identification with a range of minority group including Goths, bikers, and gays.

With the exception of Paul Roen, who declares in his 1994 High Camp: A Gay Guide to Camp and Cult Films, Volume 1, that Rocky Horror 'has little to offer, aside from Tim Curry's portrayal of Dr Frank N. Furter', most critics, including Vito Russo in his well-known work The Celluloid Closet, agree that Rocky Horror is one of the best examples of camp cinema. ${ }^{31}$ Of course, the Hollywood musical genre that Rocky Horror cleverly imitates exudes camp by definition, as Roen comments:

Any film in which people intermittently burst into song is obviously theatrical, stylized, and patently unreal. Add to this fact the fact that musicals tend to be all awash with glitter, tinsel, and garish artifice, and you begin to see why people associate camp with this genre more than any other. ${ }^{32}$

However, mainstream audiences do not always associate camp with homosexuality, probably because, as Harry M. Benshoff points out in his book Monsters in the Closet, 'both cultural critics and everyday moviegoers often seem all too willing to ignore the homosexual implications of popular culture artifacts'. ${ }^{33}$ By combining campy musical and overt homosexual content, The Rocky Horror Picture Show makes it difficult for audience to avoid this association. Thus, O'Brien presents his audience with a story inspired by Shelley's Frankenstein that chooses to revisit the novel's sexual content and offers an explicit endorsement of Shelley's fluid presentation of sexual categories.

The Rocky Horror Picture Show is not only a camp film but also a cult favorite, in ways that resembles Shelley's cultural standing as one of the most well known literary archetypes and also one of the novels most adapted for television and cinema. Regular late-night performances of The Rocky Horror across the continent and the quasi-mythical ritual that every showing elicits from its audience clearly attest to the film's cult status. As Amittai F. Aviram notes, one can easily ascribe the term cult to The Rocky Horror in its classical sense, [that is to say] the celebration of mystic rites pertaining to a divine being or divine beings and to the appropriate secret lore'. ${ }^{34}$ The way members of the audience dress for a viewing certainly evokes this idea of a ritual event, but it is the character of Frank N. Furter which embodies the idea of cult behaviour in an extreme form. Aviram considers Frank to be 'a postmodern, gay version of the god Dionysus'. 35 Whatever god Frank might personify, he undoubtedly has many god-like characteristics, the first of which is his evident ability to create life. As he announces in the laboratory scene, he has discovered 'the secret - that elusive ingredient - that spark that is the breath of life. Yes - I have that knowledge, I hold the key to life itself.' Frank goes on to sing of how 'In just seven days, I can make you a man', clearly parodying God's creation of the world as described in Genesis. ${ }^{36}$ In the song 'Rose Tint my World', Frank's divine ability is again brought to the fore when he manipulates other characters' 
bodies as if they were puppets, dressing them up in fancy lingerie and arranging them on the stage for the 'Floor Show.' It is again reinforced when, during the 'Floor Show', Rocky sings, 'I'm just seven hours old'.

Throughout The Rocky Horror Picture Show, the biblical references repeatedly mix with literary and popular culture references, 'incorporating visual and verbal allusions to everything from The Wizard of $\mathrm{Oz}$ to Michelangelo's Creation of Adam', creating a multi-layered film that proves to be more complex and difficult to analyse in detail than it may appear at first to the viewer. ${ }^{37}$ The sexual dimension of The Rocky Horror Picture Show is one of the most obvious and most discussed aspects of the film. James Twitchell, for instance, shrewdly argues that 'Rocky Horror is a celebration of a meridian crossing, the last stage of latency, the acceptance of procreative sexual roles. ${ }^{38}$

Similarly, readers of Shelley's novel have been both fascinated and offended by her story, the power Victor Frankenstein possesses, and the threat that the Creature embodies. The body of the Creature is repulsive on some level because of its hideousness, and its muscular shape asserts the Creature's physical power, as well as its potential sexual threat. This latter threat was made more explicit in the first released version of Whale's 1931 film when the scene between Karloff and the little girl was partially cut, ultimately reinforcing the Creature's implied physical and sexual power. ${ }^{39}$ It can be argued that the particular sexual horror associated with the Creature has also more to do with homosexuality than with heterosexuality. As Benshoff has persuasively demonstrated, the concepts of 'monster' and 'homosexual' share, as he puts it, 'many of the same semantic charges and arouse many of the same fears about sex and death'.40

The Rocky Horror embodies these fears in the Creature, as in Shelley's novel, but also more specifically in its creator, Frank N. Furter. The film makes explicit the fact that Rocky is nothing but a sexual object for Frank, who acknowledges having made him for his personal sexual enjoyment. During Rocky's first song 'The Sword of Damocles', Frank runs after him and tries to touch him repeatedly. The following song 'I Can Make You a Man' illustrates further Frank's sexually oriented thoughts regarding Rocky when he touches him again, and explains that Rocky will work hard in the gymnasium to become 'a strong man'. (Rocky seems unaware of Frank's plan for him as Frank sings to the audience 'if he only knew of my plan'). Frank then asks Janet what she thinks of Rocky, and, when she declares not liking men with too many muscles, Frank announces, 'I didn't make it for you.' The wedding music playing in the background as Frank and Rocky head for the nuptial bedroom, and the subsequent image of Rocky happily asleep on the bed, leaves no doubt about the sexual nature of their relationship. ${ }^{41}$ Finally, Rocky himself demonstrates his exclusively sexual purpose in life by showing off his muscular body repeatedly throughout the film. His longest statement in 'Rose tint my world' emphasizes again the purpose of his existence:

I'm just seven hours old

And truly beautiful to behold.

And somebody should be told 
My libido hasn't been controlled.

Now the only thing I've come to trust

Is an orgasmic rush of lust.

This 'orgasmic rush of lust' which progressively overtakes all the characters involved in the 'Floor Show', including the very stern Dr Scott, originates from Frank and the sexual attitude he advocates. Ultimately, as Russo insightfully asserts,

Tim Curry's performance ... is the essence of what every parent in America fears will happen if ... sexual standards are relaxed. It becomes the living horror of making deviant sexuality visible and tangible in the only kind of setting in which it could possibly work, an old dark house populated by lesbians, transvestites, acid freaks and goons who sing rock and roll as they seduce the innocent youth of America. ${ }^{42}$

The innocent youth of America, as represented by Brad and Janet, are unquestionably seduced, as their performance during the 'Floor Show' demonstrates. They sing along, with great enthusiasm, to Frank's hymn to sexual pleasure and enjoyment of life:

We're a wild and an untamed thing.

We're a bee with a deadly sting.

You get a hit and your mind goes ping.

Your heart'll thump and your blood will sing.

So let the party and the sounds rock on.

We're gonna shake it 'till the life has gone.

Frank's famous line 'Don't dream it, be it' that he repeats numerous times during the 'Rose Tint my World' sequence is the essence of his philosophy: he invites everyone to turn their sexual fantasies into sexual liberties. However, this sexual liberty is only possible for a while before the norms of heterosexual society reassert themselves upon the straight characters of Brad, Janet, and Dr Scott. The openly bisexual characters of Frank, Columbia, and Rocky cannot survive because, in the words of Scott, 'Society must be protected.' Incidentally, the question of protection takes another form in the current musical version of The Rocky Horror Show, which still regularly tours around England and has had successful runs in Los Angeles and New York. In this updated version, after Brad and Frank have had sexual intercourse, Frank waves a used condom in the air as he says 'I know - but it wasn't all bad was it? Not really even half bad, in fact, I think you found it quite pleasurable.' The doors to sexual freedom are still wide open in this updated version of the musical, but in an age of awareness of sexually transmitted diseases, precautions are to be enforced, even by transvestite aliens.

I would like to conclude this essay by again quoting Kilgore's essay 'Sexuality and Identity in The Rocky Horror Picture Show', in which he writes that 'The film moves from a raucous celebration of sexuality, through a lament for its dangers and confusions, to a final, sporting admission of the need to control it'.43 Although I agree overall with Kilgore's argument in his article, I do not think that Rocky Horror 
endorses the need for control that seems to be present at the end of the film. On the contrary, this film reiterates how much the mainstream, heterosexual society fears, and wants to be rid of, what it considers to be sexual deviancy. Paradoxically, the agents of mainstream, heterosexual society emerge in the form of Riff Raff and his sister Magenta, both of whom are perceived as incestuous, and at least one of whom is also bisexual. ${ }^{44}$ The penultimate song 'Super Heroes', with its fatalistic lines 'And crawling on the planet's face / Some insects called the human race, undermines society's capacity to be self-reflective. The last song 'Science-Fiction Double Feature' admits that 'Frank has built and lost his creature', but it also says that, without him, 'Darkness has [again] conquered Brad and Janet.'

The parodic elements of conventions from horror and musical films throughout The Rocky Horror Picture Show also suggest that the narrative closure of the film is not as conventional as it may appear. In fact, O'Brien cleverly echoes Shelley's story-within-a-story frame narrative by using the character of the narrator throughout his film. The narrator guides the viewers through a story that has already happened and is being narrated once again for their interest, thus implying a sense of repetition rather than closure. The narrator's intrusions throughout the film, even providing a written description of the time-warp dance, repeatedly underlines the constructed nature of The Rocky Horror Picture Show, both from a film perspective - with cuts and jumps from one location to another - and from a narrative one. The nature of The Rocky Horror as a cult film further complicates the apparent narrative ending, with fans compulsively re-screening and re-enacting the film. Ultimately, O'Brien's film proves to be a work of art in its own right which, as George Linden says of successful adaptations of novels, 'excites the reader to go re-experience that work in another medium: the novel'. 45

\section{Notes}

I would like to thank Emma Clery and Joel Pace for their comments on earlier versions of this essay.

1 James A. W. Hefferman, 'Looking at the Monster: Frankenstein and Film', Critical Inquiry, 24/1 (1997), 133.

2 Mary Wollstonecraft Shelley, The Letters of Mary Wollstonecraft Shelley, 3 vols. ed. Betty T. Bennett (Baltimore and London: Johns Hopkins University Press, 1980-88), Vol. I, p. 369 .

3 Parts of my discussion of the homosexual aspect of Shelley's novel come from my article 'Science, Gender and Otherness in Shelley's Frankenstein and Kenneth Branagh's Film Adaptation', European Romantic Review, 9/2 (Spring 1998), 253-70. I am grateful to the editors of this journal for granting me the permission to use some of my previously published material.

4 Mary Shelley, Frankenstein, ed. J. Paul Hunter (New York and London: W. W. Norton \& Company, 1996), p. 15. Further references are to this edition and will be given in parentheses in the text.

5 Mark Simpson, Male Impersonators: Men Performing Masculinity (New York: Routledge, 1994), p. 7; emphasis mine. 
6 Whale's position as an openly gay man directing a mainstream Hollywood film is obviously worth bearing in mind when considering his directorial decision since it could be argued that by participating in mainstream cinema, Whale is actually challenging it at the same time.

7 Steve Neale, 'Prologue: Masculinity as Spectacle - Reflections on Men and Mainstream Cinema', in Steven Cohan and Ina Rae Hark, eds, Screening the Male: Exploring Masculinities in Hollywood Cinema (London and New York: Routledge, 1993), p. 19.

8 For clarity's sake, I refer to Victor as Victor throughout this essay, even though his name is Henry in Whale's films. (Victor is called Henry in the play on which Whale's film is based.)

9 Gordon D. Hirsch, 'The Monster was a Lady: On the Psychology of Mary Shelley's Frankenstein', Hartford Studies in Literature, 7/2 (1995), 126; David E. Musselwhite, Partings Welded Together: Politics and Desire in the Nineteenth-Century English Novel (London and New York: Methuen, 1987), pp. 62-4.

10 Judith Halberstam, Skin Shows: Gothic Horror and the Technology of Monsters (Durham and London: Duke University Press, 1995), p. 42.

11 Eve Kosofsky Sedgwick, Between Men: English Literature and Male Homosocial Desire (New York: Columbia University Press, 1992 [1985]), pp. 91-2.

12 Margaret Homans, Bearing the Word: Language and Female Experience in NineteenthCentury Women's Writing (Chicago: University of Chicago Press, 1986), p. 104.

13 Charles Robinson, ed. The Frankenstein Notebooks: A Facsimile Edition of Mary Shelley's Manuscript Novel, 1816-17, 2 vols. (New York and London: Garland Publishing Inc., 1996), Vol. 2, p. 541.

14 Whale had been an actor, stage designer, and director of numerous plays in England in the 1920s, including Sherriff's Journey's End. Whale's directing of this play was a success not only in London but also in the United States, and this eventually opened doors to him in Hollywood. He was also directly involved in the screenplay adaptation of Webling's play.

15 Brian Easlea, Fathering the Unthinkable: Masculinity, Science and the Nuclear Arms Race (London: Pluto Press, 1983), p. 35.

16 Brian Aldiss, The Detached Retina: Aspects of SF and Fantasy (New York: Syracuse University Press, 1995), p. 78.

17 I borrow this term from Helen W. Robbins' discussion of David Cronenberg's The Fly and Dead Ringers, in which she defines 'womb envy' as 'a feeling of impotence clearly stemming from jealousy of female reproductive power' ("More Human than I am Alone": Womb Envy in David Cronenberg's The Fly and Dead Ringers', in Cohan and Hark, eds, Screening the Male, p. 135).

18 Chris Baldick, In Frankenstein's Shadow: Myth, Monstrosity, and Nineteenth-century Writing (Oxford: Clarendon Press, 1987), p. 32.

19 Kenneth Branagh, Mary Shelley's Frankenstein: The Classic Tale of Terror Reborn on Film (New York: Newmarket Press, 1994), p. 9. Although it could be argued that Shelley did not have this sort of reinterpretation in mind when she wrote the novel, theatre adaptation of novels was a common practice in the Romantic period. One of her father's novel, Caleb Williams, was adapted for the stage, as was Frankenstein numerous times during the nineteenth century, starting in 1823 with Peake's Presumption: or, the Fate of Frankenstein.

20 Jean-François Lyotard, 'Acinema', in The Lyotard Reader, ed. Andrew Benjamin (Oxford: Blackwell, 1989), p. 174. 
21 Kenneth Branagh, 'With Mary Shelley's Frankenstein, Kenneth Branagh Re-animates a Big Screen Classic', Interview by Ray Greene, Box Office (November 1994), unpaginated. Available on-line at http://www.boxoff.com/branagh.html, accessed 12/09/95.

22 Aldiss, The Detached Retina, p. 78.

23 Bouriana Zakharieva, 'Frankenstein of the Nineties: The Composite Body', Canadian Review of Comparative Literature, 23/3 (1996), 745.

24 Charles Robinson, ed. The Frankenstein Notebooks, Vol. 1, p. 97.

25 Paul Burston, 'Just a Gigolo? Narcissism, Nellyism and the "New Man" Theme', in A Queer Romance: Lesbians, Gay Men and Popular Culture, ed. Paul Burston and Colin Richardson (London and New York: Routledge, 1995), p. 111.

Ellen Moers, 'Female Gothic: The Monster's Mother', in Literary Women (New York: Doubleday, 1976), reprinted in Mary Shelley, Frankenstein, p. 218.

Gilles Deleuze, Cinema 2: The Time Image, trans. Hugh Tomlinson and Robert Galeta (Minneapolis: University of Minnesota Press, 1989), p. 189.

28 Branagh, Mary Shelley's Frankenstein, p. 81.

29 Stuart Samuels, Midnight Movies (New York: Collier Books, 1983), p. 128.

30 Neale, 'Prologue', p. 11.

31 Paul Roen, High Camp: A Gay Guide to Camp and Cult Films (San Francisco: Leyland Publications, 1994), Vol. 1, p. 170.

32 Ibid., pp. 11-12.

33 Harry M. Benshoff, Monsters in the Closet: Homosexuality and the Horror Film (Manchester and New York: Manchester University Press, 1997), p. 291.

34 Amittai F. Aviram, 'Postmodern Gay Dionysus: Dr Frank N. Furter', Journal of Popular Culture, 26/3 (1992), 183.

35 Ibid., p. 183.

36 In the song 'I Can Make You a Man', Frank also parodies the 1950s Charles Atlas advertisements, where a thirty-day program for home exercise would improve your physical appearance and turn you into a 'man', i.e. a muscular man.

37 John Kilgore, 'Sexuality and Identity in The Rocky Horror Picture Show', in Eros in the Mind's Eye: Sexuality and the Fantastic in Art and Film, ed. Donald Palumbo (New York, Westport, Connecticut and London: Greenwood Press, 1986), p. 153.

38 James B. Twitchell, Dreadful Pleasures: An Anatomy of Modern Horror (New York and Oxford: Oxford University Press, 1985), p. 202.

39 This essay does not consider Mel Brook's 1974 Young Frankenstein, but this film possibly offers the most explicit reading of the Creature's sexual prowess.

40 Benshoff, Monsters in the Closet, p. 3.

41 It is interesting to note that this scene did not feature in the original staged musical version of The Rocky Horror Show, as Patricia Quinn (who played Magenta on stage and in the film) remarks in the audio commentary available in the DVD version of the film. O'Brien thus deliberately left no doubt in his viewers' mind about the outcome of the evening for Frank and Rocky.

42 Vito Russo, The Celluloid Closet: Homosexuality in the Movies, revised ed. (New York and Cambridge: Harper \& Row, Publishers, 1987), pp. 52-3.

43 Kilgore, 'Sexuality and Identity', p. 159.

44 Although not the topic of this essay, the fact that Riff Raff and Magenta function as servants to a libertine aristocrat-figure throughout most of the film brings up the topic of class issues at play in The Rocky Horror Picture Show. There is indeed more to be said about the social background of the various characters, from the lower-class, 
uneducated character of Eddy to the upper middle-class, university educated characters of Brad and Janet. O'Brien engagingly combines class issues with sexual politics and moralistic views in an effort to undermine more stereotypes.

45 George Linden, 'The Storied World', in Film and Literature: Contrasts in Media, ed. Fred H. Marcus (New York: Chandler, 1971), p. 71.

\section{Address for correspondence}

Michael Eberle-Sinatra, Département d'études anglaises, Université de Montréal, CP 6128, Station Centre-ville, Montréal, Quebec H3C3J7 Canada. E-mail. michael.eberle.sinatra $@$ umontreal.ca 